\title{
Use of elder donors for cadaveric single kidney transplantation: a new evolution or an inacceptable risk?
}

F Melandro, Q Lai, F Nudo, G Spoletini, GB Levi Sandri, L Poli, R Pretagostini, PB Berloco

From XXIII Annual Meeting of the Italian Society of Geriatric Surgery

Lecce, Italy. 2-4 December 2010

\section{Background}

Organ shortage and long waiting times represent relevant issues in modern kidney transplantation [1]. Expan- sion of the donor pool using Extended Criteria Donors (ECD) represents a way to partially resolve these limits. ECDs are defined by UNOS as $\geq 60$-year aged donors or

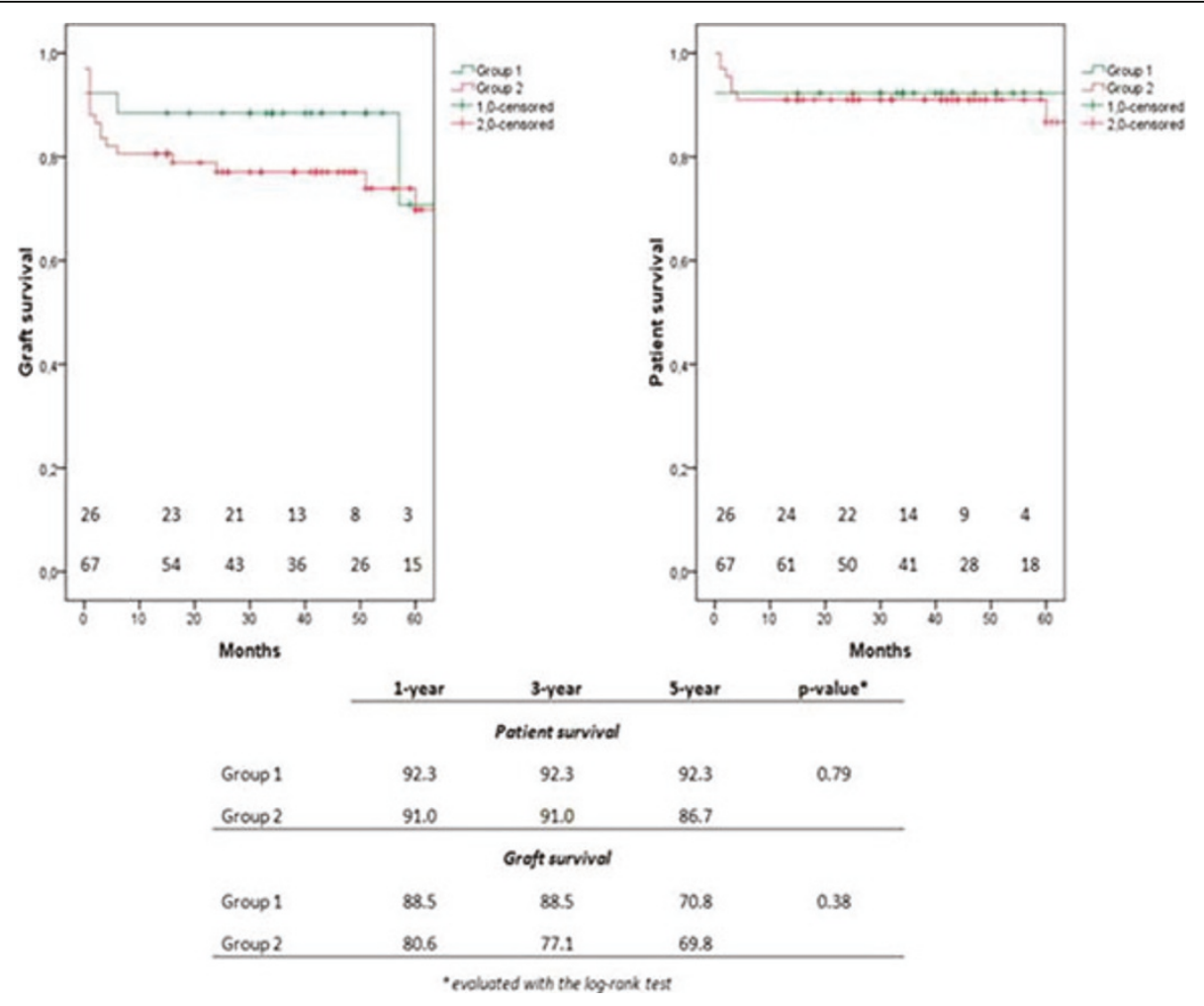

Figure 1 Graft and patient survivals in the 2 groups

\footnotetext{
* Correspondence: lai.quirino@libero.it

Department of General Surgery and Organ Transplantation, Sapienza

University, Rome, Italy

Full list of author information is available at the end of the article
} 
50-59-year aged donors with at least 2 of 3 risk factors (pre-procurement serum creatinine $>1.4 \mathrm{mg} / \mathrm{dl}$, cerebrovascular accident and history of hypertension) [2]. However, use of ECD seems to be related to worse results in terms of graft function and survival [3]. Moreover, no data exist with regard to comparison between over-60 and 50-59-year aged donors. The aim of this study is to analyze the cohort of ECD transplants performed in our Department, evaluating the role of donor age on results.

\section{Materials and methods}

From January 2004 to May 2009, 95 single kidney transplantations using ECDs were performed. The entire cohort was stratified in 2 groups: Group A (50-59 years, $\mathrm{n}=26$ ) and Group B ( $\geq 60$ years, $\mathrm{n}=69$ ). Donor, recipient and transplant characteristics were compared using the chi-squared and the Mann-Whitney test. Patient and graft survival were analyzed by the Kaplan-Meier method and compared using the log-rank test.

\section{Results}

Group A presented younger donors (55 vs 67 years) and recipients (53 vs 58 years), a higher number of donors with previous history of hypertension ( $92 \%$ vs $43 \%$ ) and higher pre-harvesting creatinine values (1.2 vs $0.9 \mathrm{mg} /$ dL). Post-transplant graft function did not present statistical differences. Five-year patient and graft survivals results were similar (Fig. 1).

\section{Conclusions}

Use of ECD seems to be safe, even using very elderly donors. In our experience, biopsy-driven seection is exclusively performed in over-60 donors. Starting from this consideration, we could speculate that the use of biopsy in over-60 donors allows "bad donors" to be excluded obtaining similar survival rates with respect to younger donors. Systematic use of biopsy in 50-59-year donors with risk factors could further improve outcomes.

Published: 24 August 2011

\section{References}

1. Sung RS, Guidinger MK, Lake CD, McBride MA, Greenstein SM, Delmonico FL, et al: Impact of the expanded criteria donor allocation system on the use of expanded criteria donor kidneys. Transp/ 2005, 79:1257-1261.

2. Metzger RA, Delmonico FL, Feng S, Port FK, Wynn JJ, Merion RM: Expanded criteria donors for kidney transplantation. Am J Transplant 2003, 3(suppl 4):114.

3. Stratta RJ, Rohr MS, Sundberg AK, Farney AC, Hartmann EL, Moore PS, et al: Intermediate-term outcomes with expanded criteria deceased donors in kidney transplantation: a spectrum or specter of quality? Ann Surg 2006, 243:594-601.
doi:10.1186/1471-2318-11-S1-A34

Cite this article as: Melandro et al:: Use of elder donors for cadaveric single kidney transplantation: a new evolution or an inacceptable risk? BMC Geriatrics 2011 11(Suppl 1):A34.

\section{Submit your next manuscript to BioMed Central and take full advantage of:}

- Convenient online submission

- Thorough peer review

- No space constraints or color figure charges

- Immediate publication on acceptance

- Inclusion in PubMed, CAS, Scopus and Google Scholar

- Research which is freely available for redistribution

Submit your manuscript at www.biomedcentral.com/submit 